\title{
ANT TRAP NESTS ENABLE DETECTION OF A RARE AND LOCALISED BUTTERFLY, ACRODIPSAS MYRMECOPHILA (WATERHOUSE AND LYELL) (LEPIDOPTERA: LYCAENIDAE) IN THE FIELD
}

\author{
D. R. BRITTON
}

Department of Biological Sciences, University of Wollongong, Northfields Avenue, Wollongong, NSW 2522, Australia

\begin{abstract}
Britton, D.R., 1997. Ant trap nests enable detection of a rare and localised butterfly, Acrodipsas myrmecophila (Waterhouse and Lyell) (Lepidoptera: Lycaenidae) in the field. Memoirs of the Museum of Victoria 56(2): 383-387.

Location of the ant Papyrius nitidus is essential in order to determine critical habitat for the rare butterfly Acrodipsas myrmecophila, which is known in Victoria from a single locality (Mount Piper). This paper describes the location of $P$. nitidus colonies at Mount Piper and the subsequent detection of immature stages of $A$. myrmecophila in a $P$. nitidus colony. The benefits of trap nests for detection, observation and conservation of the ant/butterfly association are outlined and discussed.
\end{abstract}

\section{Introduction}

The Small Ant-blue, Acrodipsas myrmecophila (Waterhouse and Lyell), is a rare butterfly in Victoria, and is scarce and localised throughout the rest of Australia. It has a single current Victorian locality at Mount Piper $\left(32^{\circ} 12^{\prime} \mathrm{S}\right.$, $\left.145^{\circ} 0^{\prime} \mathrm{E}\right)$, where occasional adult individuals have been taken from the summit of the mount since 1978 (D. F. Crosby, pers. comm.). This butterfly species and the related species, $A$. brisbanensis (Miskin) are listed as threatened on Schedule 2 of Victoria's Flora and Fauna Guarantee Act, 1988. These two species, and associated biota, form the basis of Butterfly Community No.1, a butterfly community listed as threatened on Schedule 2 of the same Act (Jelinek, 1991; Britton et al., 1995).

A. myrmecophila has a symbiotic relationship with an ant species Papyrius nitidus (Mayr). The larvae and pupae of the butterfly occur in nests of this ant, and the larvae are thought to be myrmecophagous (Common and Waterhouse, 1981) as is the closely related $A$. illidgei (Waterhouse and Lyell) (Sampson, 1989). The adults of most Acrodipsas spp., particularly males, congregate on hill-tops; several species are known only from adults collected from hill-tops (Common and Waterhouse, 1981).

A. myrmecophila has been recorded from only a few Victorian localities, all of which have suffered from changes in habitat. Colonies were known from Ocean Grove, Ringwood, Wandin, Heathmont and Broadford. The butterfly is almost certainly extinct at Ocean Grove,
Wandin, Heathmont and Ringwood, and the original colonies at Broadford have disappeared. It is also known from a few specimens taken at isolated localities (mostly hill-tops) in New South Wales, Queensland (including a single record from Cape York), and from a single record near Darwin, in the Northern Territory (Common and Waterhouse, 1981; Dunn and Dunn, 1991). A breeding colony has been recorded from Milmerran, Queensland (Common and Waterhouse, 1981), but the current status of this population is not known.

In order to prepare a sound management plan to conserve the population of $A$. myrmecophila at the Mount Piper locality it was necessary to determine the critical habitat for this species; this formed part of the recovery plan (research phase) for Butterfly Community No. 1 (Jelinek, 1992). Presence of the host ant, Papyrius nitidus, is an essential requirement for the butterfly. $P$. nitidus has been the target of concerted search efforts by researchers at Mount Piper for the past four years (Britton and New, 1992, 1993; Hinkley, 1993; New et al., 1994; Beardsell, 1994; Miller, 1994). Direct searches in farmland, roadside verges and bushland in and around the Mount Piper reserve have failed to locate ant colonies, as has pitfall trapping on the wooded slopes of the reserve and private land on the mountain (Britton and New, 1992; Hinkley, 1993), and in grasslands east of the reserve (Miller, 1994). These efforts have resulted in the collection of a large body of information about the ant communities present in the Mount Piper 
region (New et al., in press) and butterfly communities (Britton et al., 1995).

This paper describes the successful location of $P$. nitidus and the subsequent discovery of immature stages of $A$. myrmecophila at Mount Piper, and describes some aspects of the distribution, biology and behaviour of $P$. nitidus and A. myrmecophila. The use of trap nests for survey and conservation research is described and discussed.

\section{Methods}

\section{Surveys}

Surveys in the 1994/95 season consisted of visually searching suitable areas as defined by Beardsell (1994). Previous work at Mount Piper included searches of the more heavily wooded slopes (Britton and New, 1992; 1993; New et al., 1994). Habitat requirements for Papyrius nitidus in other regions of Victoria are sunny and well-drained ridges and slopes under a tree stratum that does not exceed $25 \%$ projected foliage cover and on slopes that do not exceed 25\% inclination (Beardsell, 1994). This excludes most of the Mount Piper Education Reserve, and some private land adjoining the reserve, hence most searches over the 1994-1995 season were in private land east, west and south-west of the mountain.

\section{Design and construction of trap nests}

The trap nests used in this study were based on a design by C. Beardsell. Papyrius spp. normally nest in dead wood, soil and at the base of living trees. The trap nests were designed to be attractive to the ants, and to provide a dry, safe space for the ants to nest in. The trap nests needed to be opened and inspected at regular intervals.

The nests were made from old hardwood. Care was taken to avoid wood that had been treated with any chemicals (e.g., creosote) that might deter or kill the ants. Old railway sleepers and fence strainers were used for the initial six trap nests, whose dimensions varied from 47 to $62 \mathrm{~cm}$ long, 11 to $32 \mathrm{~cm}$ wide, and 10 to $15 \mathrm{~cm}$ deep.

The trap nests were made by cutting the wood in half lengthwise. The bottom-half was then grooved to form nest cavities which were connected to the outside of the nest and each other by entrance tunnels (Figure 1). Trap nests were washed with a non-scented detergent (TrukWash) then left out in the sun for a week to bleach out traces of detergent which may be toxic to the ants. The two halves were held together by metal straps and clamps (Emlocks, available from apiarists supplies).

Six trap nests were placed adjacent to saplings colonised by the ant in the eastern colony ( 4 Jan 1995) (Figure 2). The traps were inspected eight times between 6 Jan 1995 and 2 Mar 1995.
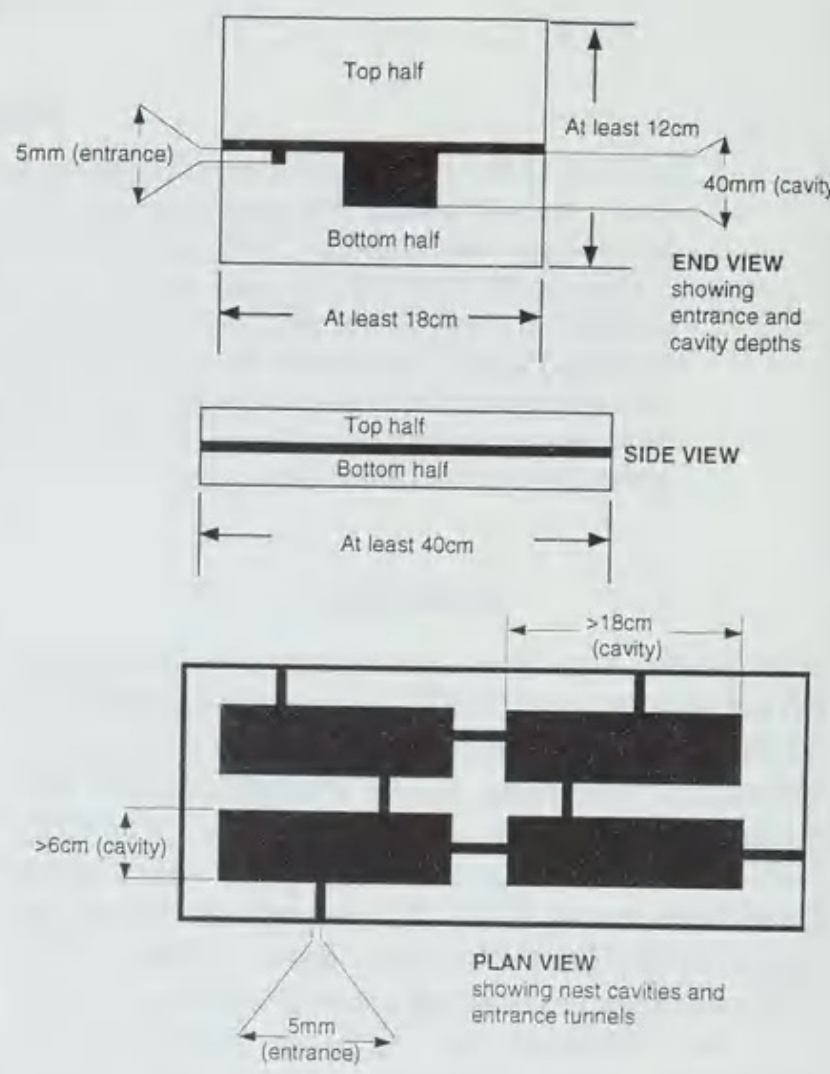

Figure 1. Schematic diagram of trap nests with approximate measurements. Diagram is not to scale.

\section{Results}

A P. nitidus colony, covering an area of about 25 $\times 15 \mathrm{~m}$, was located in private land to the east of the reserve (23 Oct 1994), and was later found to harbour immature stages of the Small Ant Blue butterfly, Acrodipsas myrmecophila. The above ground portions of the colony consisted of a dead tree stump ( $39 \mathrm{~cm}$ wide, $38 \mathrm{~cm}$ high), some small flat pieces of wood adjacent to this stump and about six immature Red Box (Eucalyptus polyanthemos) including a semi-mature tree and five much smaller trees. The small trees are coppice regrowth from the underground portions of lignotubers left after the original sapling trees were removed, and have a multi-trunked appearance similar to mallee eucalypts. The ant 

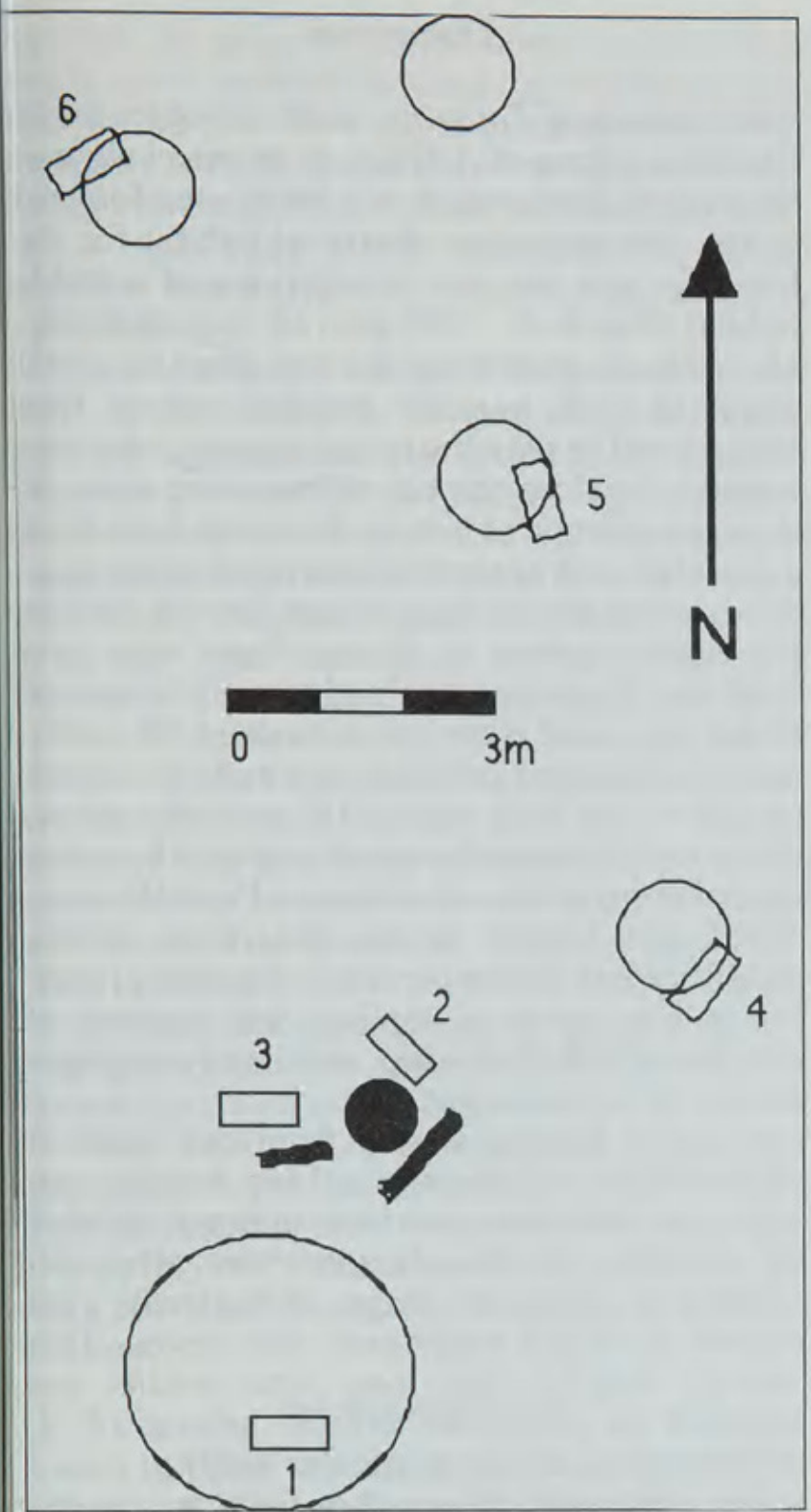

Figure 2. Placement of trap nests within the area occupied by $P$. nitidus. Open circles represent live eucalypts; the larger the circle, the greater the height and canopy width of the tree. Filled shapes represent dead wood on the ground, including the stump. Rectangles indicate trap nests, which are identified by numbers.

constructed byres of carton at the base of the coppice regrowth, as well as over the stump and other pieces of dead wood. The carton covering was conspicuous on the stump, and was the key factor in finding the colony.

This colony was only $20-25 \mathrm{~m}$ away from a pitfall grid operated fortnightly from February to July, 1994 (Miller, 1994). In spite of the proximity of this pitfall grid to the ant colony no individuals of $P$. nitidus were taken in pitfall samples, implying that the ant is restricted to the immediate area of the colony.
The ant colony was mostly underground; suitable nesting substrate above the ground was scarce. The extent of the subterranean colony could not be estimated. Ants were observed foraging on the eucalypts during daylight hours. The extent of nocturnal foraging was not established. Ants foraged in temperatures ranging from $15^{\circ} \mathrm{C}$ to over $37^{\circ} \mathrm{C}$, although low temperature observations were not made. Foraging workers visited various honeydew-producing Homoptera, including female and nymphal Coccoidea, psyllid nymphs and eurymelid leaf-hoppers. These resources were not present in the area where Miller (1994) had a pitfall grid. Foraging did not seem to occur outside of the area colonised by the ants.

Most of the trap nests were colonised two days after being placed in the field (6 Jan 1995). Figure 3 indicates the presence of $A$. myrmecophila and $P$. nitidus in trap nests in the eastern colony during the study period. Trap nests $1,4,5$ and 6 which were next to saplings all had workers entering the nests via the entrances, or through the crack between the two halves. Nest 3 which

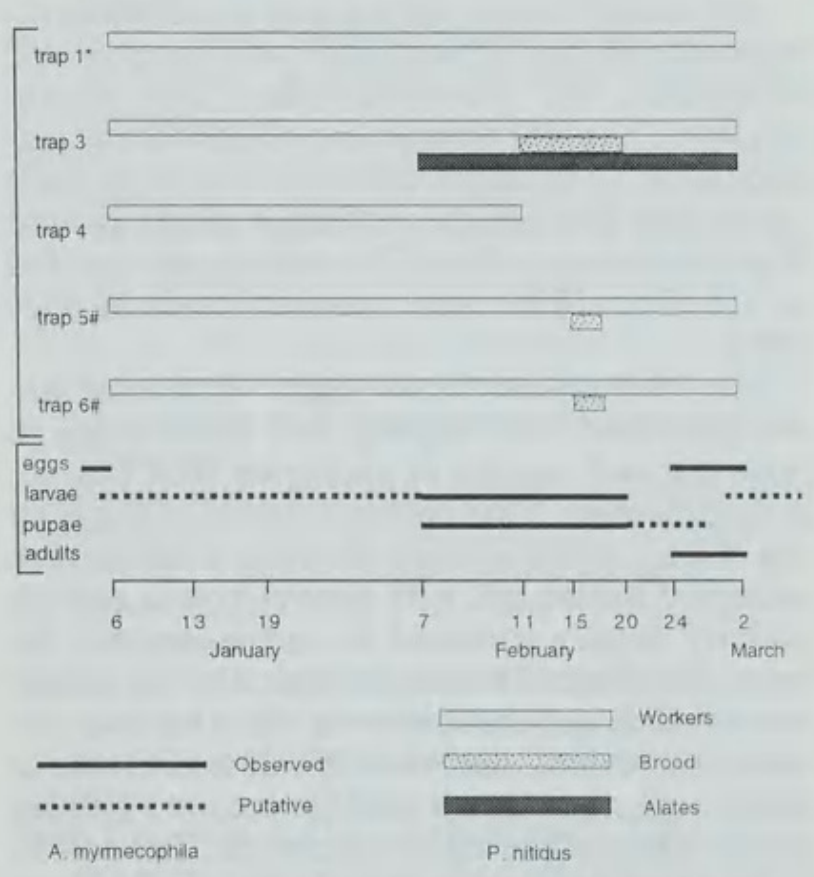

Figure 3. Presence of various life-history stages of $P$. nitidus and A. myrmecophila at Mount Piper, JanuaryMarch, 1995. Large bars represent ant activity, lines represent butterfly activity. Trap nests 5 and 6 were the only trap nests to have $A$. myrmecophila larvae and pupae present. \# indicates trap nests which had immature stages of $A$. myrmecophila present within or under them. * Trap 1 was adjacent to the eucalypt trunk with A. myrmecophila eggs. 
was adjacent to the dead stump was colonised, but nest 2 which was also next to the stump was left unoccupied during the study period. The ants placed carton in the cracks between the two halves, in nest entrances not being used for access, and in the existing holes and cracks in the nest wood. The trap nests were left undisturbed for the first month, then were lifted so that ant activity under the nest could be observed. Nests 1 and 4 were largely abandoned after the initial colonisation (6 Jan 1995), but nests 3, 5 and 6 were very active for the duration of the study. Various quantities of ant brood (larvae, pupae and callows) were observed under nests 3,5 and 6. Alate ants (winged sexual castes) were observed under nest 3 , but were not found in any of the other nests. Trap nests 5 and 6 were the only nests observed to harbour immature stages of Acrodipsas myrmecophila.

Further searching during the 1994-1995 season resulted in the location of two additional colonies of $P$. nitidus in the Mount Piper region. Both colonies were larger than the eastern colony, and were located at the base of the mountain in open grassy regions to the west and south-west.

One colony was in open grassy woodland with mature grey box (Eucalyptus microcarpa), red stringybark (E. macrorhyncha) and Acacia mearnsii. A major component of this colony was in dead wood (stumps, branches and logs), indicating that the colony was larger above ground than the eastern colony. This colony was located on 16 Dec 1994, and was revisited 28 Dec 1994.

The other colony was in open Themeda triandra grassland with sapling and mature age $A$. mearnsii and sapling or suckering Red Box ( $E$. polyanthemos). This colony resembled the eastern colony in that it had only a few small stumps occupied by the ant, with above-ground nesting activity largely confined to carton around the base of saplings. The area occupied by the colony was much larger that either of the other two colonies, but colony size was difficult to estimate as there were many small satellite colonies present on the edges of the main population. The colony is bounded by a shallow gully on the northern edge. This gully would become too wet during winter for ants to establish permanent colonies. This colony was located 23 Jan 1995.

Each colony was searched for immature stages of Acrodipsas spp. No evidence of either butterfly species was detected at these colonies.

\section{Discussion}

The location of Papyrius nitidus colonies and a breeding colony of Acrodipsas myrmecophila in the Mount Piper region is a major step forward in the determination of critical habitat for the butterfly and the ant. Predictions of suitable habitat (Beardsell, 1994) proved to be appropriate, with colonies found on well-drained gentle slopes in open, partially wooded regions. One element of the search strategy proved to be misleading. Previous records of immature stages of A. myrmecophila at historic localities have been associated with ant colonies in dead wood, (e.g., dead Acacia pycnantha at Ocean Grove). Ants in the eastern colony at Mount Piper were predominantly underground and around the base of living trees, and were inconspicuous. This situation has changed now that trap nests have been placed in the field within the eastern colony. Other requirements for suitable habitat based on observations of the ant at Mount Piper (Britton, 1995) and Cottles Bridge (Beardsell, 1994), would seem to be the presence of suitable foraging habitat, such as saplings and suckers of Acacia and Eucalyptus spp. which support populations of homopterans.

A major finding arising from our work at Mount Piper is that despite three detailed surveys over the three previous summers neither the colonies of the attendant ant (Papyrius nitidus) or immature stages of butterfly were located at Mount Piper until this survey. This strongly implies that long term studies are required to determine critical habitat of $A$. myrmecophila at any particular locality.

The refinement of searches for these invertebrates is a long-term process. Areas that had been thoroughly inspected and sampled in previous studies had populations of the ant. The biology of $P$. nitidus may influence the probability of locating new colonies. The ant is only active during the warmer part of the year (September to April), and on warm winter days, so winter searches may not be successful. The ant rarely forages outside of the colony area, so is not readily sampled by pitfall traps. The ant often moves between underground and surface parts of its nest.

However, once colonies are located, trap nests can be placed to increase ant habitat, and provide a method for assessing the presence or absence of $A$. myrmecophila. Trap nests are considered to be of critical importance in furthering the conservation management of this butterfly 
species. In addition to the above points, trap nests could be used to "seed" new habitat with the ant, to provide a captive population of the butterfly with food and to re-introduce the butterfly into areas where the ant is already present. Trap nests may allow researchers to make detailed field-based observations of the ant/butterfly biology.

Further research into the biology and ecology of $P$. nitidus is needed. The phenology of the ant and the age that colonies attain is not known. Additional monitoring of Mount Piper colonies may determine whether colonies die out and recolonise over short periods of time. The eastern colony may be recently established, as this area has been thoroughly but unsuccessfully searched in previous studies (Britton and New, 1992, 1993; New et al., 1994; Beardsell, 1994; Miller, 1994). This colony may have been established only within the last year or so. The ant colonies west and south-west need further work to determine the presence or absence of breeding colonies of Acrodipsas spp. Trap nests, particularly in the west where there is a dearth of dead wood within the colony, may be the appropriate way both to increase ant populations and locate immature stages of the butterfly.

Conservation of $A$. myrmecophila is primarily dependent upon conservation of $P$. nitidus. Further research must focus on the ecology and life-history of $P$. nitidus, and the use of trap nests may prove to be essential in gaining new information.

\section{Acknowledgments}

I wish to thank the following people and organisations: C. Beardsell, for the original concept and design of the trap nests, and for information on the biology and distribution of $P$. nitidus north of Melbourne, Dr M. F. Braby for assistance in the field, Mr D.F. Crosby for information on A. myrmecophila, Dr S. O. Shattuck (ANIC), for providing ant identifications and taxonomic information, R. Britton, for help in construction of the trap nests, property owners at Mount Piper, who allowed access to their lands, staff at Broadford, Geelong and Alexandra offices of the Deparment of Conservation and Natural Resources especially Matt White, Alexandra DCNR, Dr T.R. New, Dr L.X. Silberbauer and Ann Jelinek for comments on the manuscript, and the Department of Conservation and Natural Resources and the Australian Nature Conservation Agency for funding this study.

\section{References}

Beardsell, C., 1994. Report on field surveys from 22 October to 23 January 1994 for the Small and Large Ant-blue butterflies and their attendant ant species. Unpublished report, Department of Conservation and Natural Resources.

Britton, D.R., 1995. Research on the ecology of the Coconut Ant and breeding biology of the Small and Large Ant-blue and other target butterflies at Mount Piper. Broadford, 1994/95. Unpublished report for the Department of Conservation and Natural Resources.

Britton, D.R. and New, T.R., 1992. Ecology of the butterfly and ant community at Mount Piper, Victoria. Unpublished report for the Department of Conservation and Environment.

Britton, D.R. and New, T.R., 1993. Communities of diurnal Lepidoptera in central Victoria, with emphasis on the Mt. Piper region, Broadford. Unpublished report for the Department of Conservation and Natural Resources.

Britton, D.R., New, T.R. and Jelinek, A., 1995. Rare Lepidoptera at Mount Piper, Victoria - the role of a threatened butterfly community in advancing understanding of insect conservation. Journal of the Lepidopterists' Society 49: 97-113.

Common, I.F.B. and Waterhouse, D.F., 1981. Butterflies of Australia. Angus and Robertson: Australia.

Dunn, K.L. and Dunn, L.E., 1991, Review of the Australian butterflies. Privately published, Melbourne.

Hinkley, S., 1993. The ant fauna of Mt. Piper: an investigation of factors affecting ant species richness and distribution and the effectiveness of pitfall trapping. Unpublished Honours thesis, La Trobe University.

Jelinek, A., 1991. Butterfly Community No. 1. Flora and Fauna Guarantee Action Statement No. 6. Department of Conservation and Environment, Victoria.

Jelinek, A., 1992. A recovery plan, research phase, for a threatened butterfly community at Mt. Piper in central Victoria. Unpublished report to the Australian National Parks and Wildlife Service, Canberra.

Miller, L., 1994. Ant abundance and distribution on remnant native grasslands of $M t$. Piper, Victoria. Unpublished Honours thesis, La Trobe University.

New, T.R., Britton, D.R. and Hinkley, S., 1994. Recovery plan, research phase, for a rare and ihreatened butterfly community. Report for 1993/94 for Department of Conservation and Natural Resources. Unpublished report, Department of Conservation and Natural Resources.

New, T.R., Britton, D.R, Hinkley, S. and Miller, L. (in press) The ant fauna of Mount Piper, Broadford, and its relevance to environmental assessment and the conservation of a threatened invertebrate 


\section{$2 \mathrm{BHL}$ Biodiversity Heritage Library}

Britton, David R. 1997. "Ant trap nests enable detection of a rare and localised butterfly, Acrodipsas myrmecophila (Waterhouse and Lyell) (Lepidoptera: Lycaenidae) in the field." Memoirs of the Museum of Victoria 56(2), 383-387. https://doi.org/10.24199/j.mmv.1997.56.28.

View This Item Online: https://www.biodiversitylibrary.org/item/122980

DOI: https://doi.org/10.24199/j.mmv.1997.56.28

Permalink: https://www.biodiversitylibrary.org/partpdf/258125

\section{Holding Institution}

Museums Victoria

\section{Sponsored by}

Atlas of Living Australia

\section{Copyright \& Reuse}

Copyright Status: Permissions to digitize granted by rights holder.

This document was created from content at the Biodiversity Heritage Library, the world's largest open access digital library for biodiversity literature and archives. Visit BHL at https://www.biodiversitylibrary.org. 